International Journal of Agriculture, Environment and Bioresearch

Vol. 5, No. 01; 2020

ISSN: $2456-8643$

\title{
EFFECT OF ZINC APPLICATION METHOD ON GROWTH AND YIELD OF GREEN GRAMS
}

\author{
Consolata Mueni Muindi , James Biriah Ndiso and Esther Mwende Muindi \\ Department of Crop Sciences Pwani University P.O Box 195-80108, Kilifi
}

https://doi.org/10.35410/IJAEB.2020.5466

\begin{abstract}
Green gram (Vigna radiate 1.) is a legume in the family of fabaceae which is grown in Kenyan Coast for local consumption. Despite the crops importance as a locally available nutrient supplement, its production is constrained by land degradation leading to limiting soil fertility status. A field experiment was established during the March-June, 2019 long rains at Matuga in Kwale County. The experiment was aimed at investigating the effect of zinc application methods on soil fertility, growth and yield of green grams. Treatments were laid out in a Randomized Complete Block Design (RCBD) with three replications. The treatments included: soil zinc, foliar zinc and control .Green gram variety tested was KS20. Data collected included: Initial soil chemical properties, plant height, number of leaves per plant, number of pods per plant, grains per pod, weight of 100 grains, biomass and grain yield. Results showed that Soil zinc application method significantly promoted green grams plant height, number of leaves and nodulation rate better than foliar application method. Soil zinc applied plots recorded $15 \%$ higher yield compared to foliar zinc. From the results of this experiment, it can be concluded that soil zinc application is more effective than foliar zinc application
\end{abstract}

Keywords: Foliar zinc, soil zinc, green gram.

\section{INTRODUCTION}

Zinc is a very essential micronutrient for plant growth as it contains component of various enzyme systems for energy production, protein synthesis, and growth regulation (Schmitt, 2002). Zinc is also involved in auxin formation; activation of dehydrogenase enzymes; stabilization of ribosomal fractions (Obata et al., 1999). Zinc deficient plants also exhibit delayed maturity. The most visible zinc deficiency symptoms are short internodes and a decrease in leaf size (Rashid and Ryan, 2004).

Zinc can be applied to crops through foliar method, soil application or pelleting or seed dressing. Foliar zinc (Zn) application method involves directly spraying dissolved zinc Sulphate onto plant leaves and stem (Baloch et al., 2008; Yassen et al., 2010). The applied zinc is absorbed by the leaf epidermis, remobilized and transferred into the grain through phloem (Wu et al., 2010) with the help of several $\mathrm{Zn}$-regulating transporter proteins. It is a good application method in areas deficient of irrigation water. (Wissuva et al., 2007; Jiang et al., 2008; Stomph et al., 2011).

The efficiency of foliar zinc application in the management of $\mathrm{Zn}$ deficiency has been recorded by several researchers. While working on effect of zinc and sulfur foliar applications on 
physiological characteristics of sunflower (Helianthus annuus L.) under water deficit stress in United States of America Zafar (2005) found that foliar Zn application method significantly increased the growth, yield and yield of green grams by $20 \%$. Similarly, Ryan and El-Moneim, (2007) in implications of zinc deficiency for ameliorating toxicity in Kenya found that increasing $\mathrm{Zn}$ levels increased green grams grain yield y $34 \%$. Abdo (2001) also worked on the response of two mung bean cultivars to zinc, manganese and boron on Morphological, physiological and anatomical aspects in Cairo and also reported improved seed formation, number of seed and seed yield per plant in green grams treated with foliar zinc.

Soil applied $\mathrm{Zn}$ is more effective in increasing the plant level of the applied nutrient compared to foliar zinc (Yilmaz et al., 1997). Zn applications improve the growth and quality parameters in green grams (Thomas et al., 2007; Tayyeba et al., 2013). Kumar et al. (2010) evaluated the effect of $\mathrm{Zn}$ from Zinc sulphate on the green grams grown in saline environment, it was concluded that soil $\mathrm{Zn}$ application reduces the effects of salinity on the plants. Foliar applications of zinc have not been consistently effective in correcting deficiencies of this nutrient because it is expensive due to more fertilizer usage as it is efficient and faster in getting the nutrient into the target tissues (buds), it can also burn the plant if not applied effectively. The plant may not utilize the fertilizer well in case it is applied during windy days as it will be carried away or if it rains after application as the fertilizer is washed away. This method of application should be used on a trial basis only.

Soil application of $\mathrm{Zn}$ is slightly more effective than use of foliar application (Baloch et al., 2008; Yassen et al., 2010), so the use of this method to compensate micronutrients deficiency like $\mathrm{Zn}$ to improve grain performance in arid and semi-arid regions would be justified. Gupta et al. (2003) found that an increase of $14.8 \%$ yield was gained by soil application of $2.5 \mathrm{mg} \mathrm{kg}-1$ of $\mathrm{ZnSO} 4$ and $10.8 \%$ by foliar applications of $0.5 \% \mathrm{ZnSO} 4$ solution. Most soils in coastal areas of Kenya are acidic and deficient of micronutrients e.g $\mathrm{Zn}, \mathrm{Cu}, \mathrm{Mg}$ (Food and Agriculture Organization, 2016). ). Although $\mathrm{Zn}$ is required in small amounts, its availability is critical for several key physiological functions in plants (Graham et al 1992). Therefore the study is aimed at maximizing yield of green grams through Proper method of zinc fertilizer application for better uptake and utilization of $\mathrm{Zn}$ (Savithri et al., 2010) to overcome the malnutrition of the people in Kwale County.

\section{MATERIALS AND METHODS}

\subsection{Experiment location and description of materials}

Field experiments were carried out during the March-June, 2019 long rains in multi locational sites at Matuga and Mivumoni in Kwale County. Matuga lies between latitudes 3oS-4oS and longitudes 39o E - 40o E while Mivumoni lies between latitudes 4.330S and longitudes 39.520E in the Coastal lowlands. Kwale County is generally warm throughout the year with temperatures ranging between $24.20 \mathrm{C}$ during the coldest months (June and July) and $32 \mathrm{oC}$ during the hottest months (January and February) (Jatezold et al., 2012). The soils were sampled and chemical properties analysed following the procedures described by Okalebo et al. (2002) and they are as displayed in Table 1. 
Table 1: Initial soil chemical characteristics

\begin{tabular}{|c|c|c|c|c|c|c|c|c|c|c|c|c|}
\hline $\begin{array}{l}\text { Param } \\
\text { eters }\end{array}$ & $\begin{array}{l}\text { Soil } \\
\text { PH(w } \\
\text { ater) }\end{array}$ & $\begin{array}{l}\mathbf{N} \\
\%\end{array}$ & $\begin{array}{l}\mathbf{O} \\
\mathbf{C} \\
\%\end{array}$ & $\begin{array}{l}\text { PMg } \\
\mathrm{Kg}^{-1}\end{array}$ & $\begin{array}{l}\text { Potas } \\
\text { sium } \\
\text { MgK } \\
\mathrm{g}^{-1}\end{array}$ & $\begin{array}{l}\text { Calc } \\
\text { ium } \\
\mathrm{Mg} \\
\mathrm{Kg}^{-1}\end{array}$ & $\begin{array}{l}\text { Magne } \\
\text { sium } \\
\text { MgKg- }_{1}^{-}\end{array}$ & $\begin{array}{l}\text { Mang } \\
\text { anese } \\
\text { MgKg } \\
-1\end{array}$ & $\begin{array}{l}\text { Cop } \\
\text { per } \\
\mathbf{M g} \\
\mathbf{K g}^{-1}\end{array}$ & $\begin{array}{l}\text { Iro } \\
\mathbf{n} \\
\mathrm{Mg}^{\mathrm{Mg}} \\
\mathrm{Kg}^{-}\end{array}$ & $\begin{array}{l}\text { Zin } \\
\mathrm{c} \\
\mathbf{M g} \\
\mathbf{K g}^{-}\end{array}$ & $\begin{array}{l}\text { Sodi } \\
\text { um } \\
\mathbf{M g} \\
\mathrm{Kg}^{-1}\end{array}$ \\
\hline value & 5.89 & $\begin{array}{l}0 . \\
05\end{array}$ & $\begin{array}{l}0 . \\
31\end{array}$ & 15 & 0.1 & 1.2 & 0.37 & 0.34 & 1.43 & 6.8 & 4.2 & 0.08 \\
\hline class & $\begin{array}{l}\text { moder } \\
\text { ate } \\
\text { acid }\end{array}$ & $\begin{array}{l}\text { lo } \\
\text { w }\end{array}$ & $\begin{array}{l}\text { lo } \\
\text { w }\end{array}$ & Low & Low & low & low & $\begin{array}{l}\text { adequa } \\
\text { te }\end{array}$ & $\begin{array}{l}\text { adeq } \\
\text { uate }\end{array}$ & $\begin{array}{l}\text { Lo } \\
w\end{array}$ & low & $\begin{array}{l}\text { adeq } \\
\text { uate }\end{array}$ \\
\hline
\end{tabular}

\subsection{Experimental design and crop husbandry}

The treatments included: Control (No zinc application), foliar Zinc application and soil Zinc application .Zinc sulphate was applied as $\mathrm{Zn}$ source at a rate of $4 \mathrm{~kg}$ ha-1. Zinc fertilization of soil was performed at seeding during planting time using placement method while foliar zinc was applied one week after crop emergence on the leaves. The treatments were replicated three times in a randomized block design.

Seedbed was prepared with the help of tractor mounted cultivator followed by planting four days after occurrence of rainfall when the field reached to workable moisture conditions. The crop was sown on march 10,2019 on well prepared seedbed with a spacing of $45 \mathrm{~cm}$ by $15 \mathrm{~cm}$. Each experimental plot measured $2 \mathrm{~m}$ by $1.5 \mathrm{~m}$ ᄀwith five rows and each row was planted with 10 seedlings resulting to a total plant population of 450 . Individual plots were separated by $0.5 \mathrm{~m}$ wide gap while blocks were separated by $1 \mathrm{~m}$ gap leading to a total experimental plot $24 \mathrm{~m}$ by 8.5 $\mathrm{m}$.

For maintaining an appropriate plant to plant distance of $20 \mathrm{~cm}$, thinning was made at 4-leaf stage. Weeds were controlled by manual hoeing at 4-leaf stage. Crop was harvested manually at physiological maturity, sundried for 10 days and then shelled manually.

\subsection{Data collection}

Ten plants were tagged randomly from the middle rows of each plot 14 days after emergence and the tagged plants were used for biological and economic yield data collection throughout the experimental period. Plant height were determined by measuring the height of the ten tagged plants from the base of plant to the longest leaf by use of a ruler on weekly basis from two weeks after emergence till physiological maturity.

Number of leaves was determined by counting all the leaves from the ten tagged plants from one week after emergence on weekly basis until physiological maturity. Number of pods per plant and number of grains per pod were determined by counting the ten tagged plants per plot at harvesting time. Number of days to $50 \%$ flowering and pod formation were recorded. 
Physiological maturity was determined when the green grams color changed from green to brown.

Weight of 100-grains was determined by weighing 100 grains of the harvested grains per plot. Grain yield were determined by harvesting mature plants from an area of $1 \mathrm{M} 2$ in the middle part of the plot and weigh them.

\subsection{Statistical analysis}

All obtained data were subjected to analysis of Variance (ANOVA) using general linear model (GLM) SAS Computer package version 9.1. Means were separated using the Duncan's New Multiple Range Test at 5\% level of significance (Steel and Torrie, 1980).

\section{RESULTS}

\subsection{Effects of zinc application methods on green gram height}

Zinc application methods significantly $(\mathrm{P} \leq 0.05)$ affected green grams height both in (Fig 1$)$ and (table 2). Soil applied zinc recorded the highest plant height throughout the data collection period compared to the other treatments. There was no significance difference in plant height among treatments from week one to four. Plant height, however, significantly varied with treatment from week five after crop emergence.

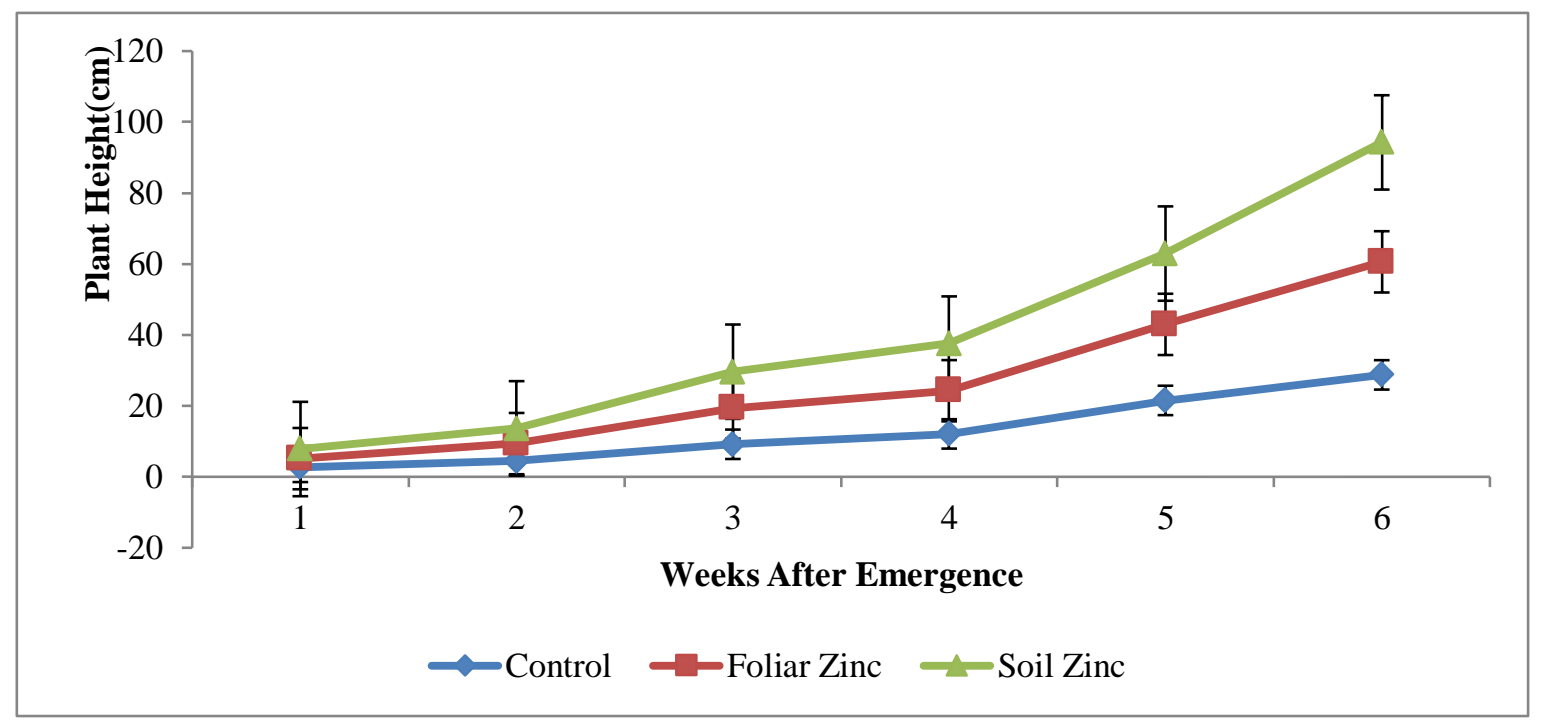

Fig1: Effects of zinc application methods on green grams plant height $(\mathrm{cm})$.

\section{2. Effects of zinc application methods on green grams leaf number}

Number of leaves per plant were significantly $(\mathrm{P} \leq 0.05)$ influenced by zinc application methods (Fig2). Soil zinc recorded the highest leave numbers per plant while control recorded the least throughout the data collection period (table 2). Leaf numbers significantly varied with treatment from week four to week six (Fig2). 


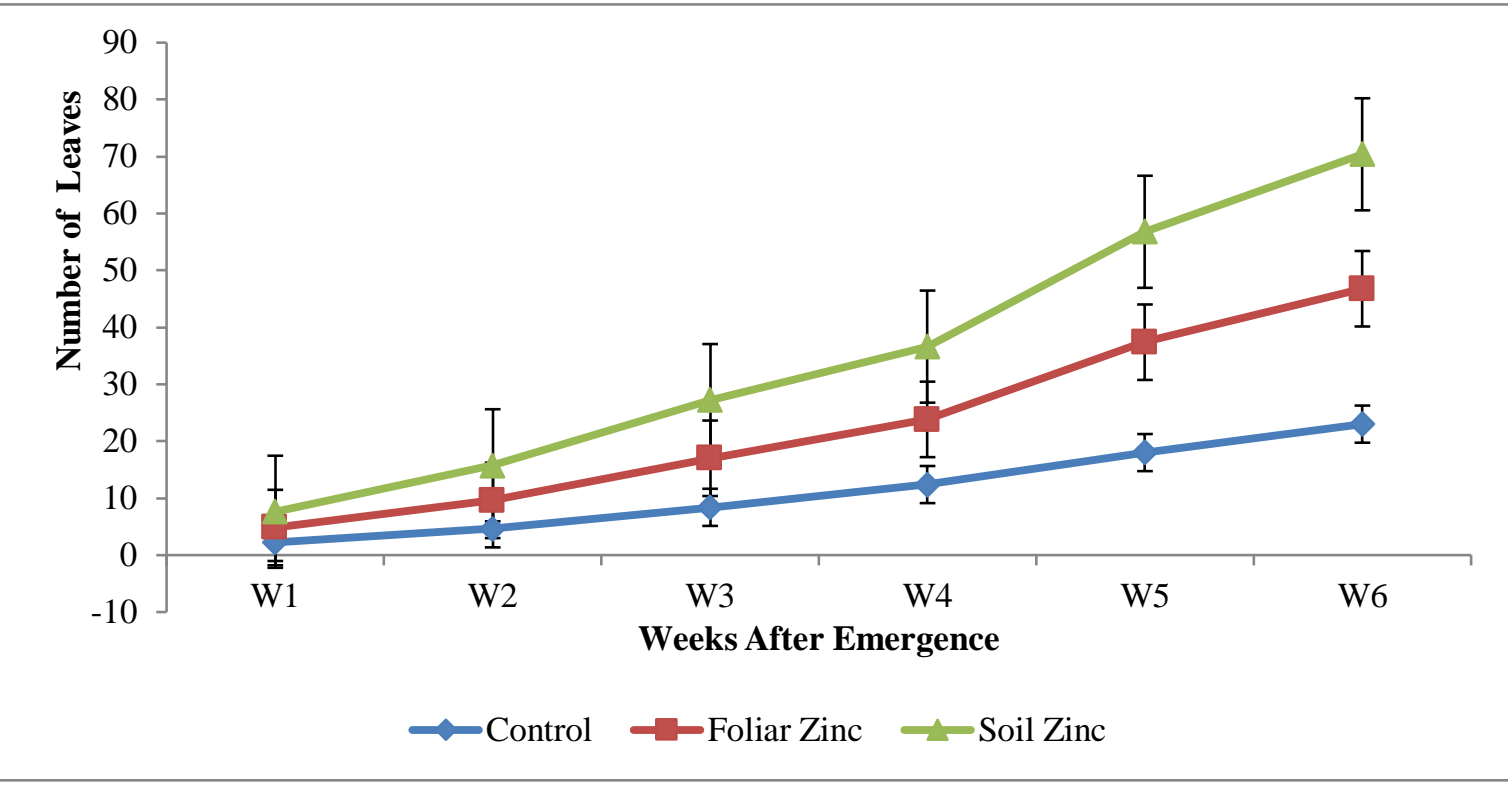

Fig .2: Effects of zinc application methods on leaf number in green grams.

Table 2: Effect of zinc application method on green grams height and leaf number.

\begin{tabular}{|c|c|c|}
\hline Treatments & Plant Height & Leaf Number \\
\hline Foliar Zinc & $16.3 \mathrm{de}$ & $11.9 \mathrm{~d}$ \\
\hline Soil Zinc & $17.3 \mathrm{de}$ & $12.4 \mathrm{~d}$ \\
\hline Control & $15.1 \mathrm{e}$ & $11.5 \mathrm{~d}$ \\
\hline MEAN & 18.8 & 15.1 \\
\hline $\mathrm{CV}(\%)$ & 7.7 & 5.6 \\
\hline LSD & 0.8 & 0.5 \\
\hline $\mathrm{P} \leq 0.05$ & $<.0001$ & $<.0001$ \\
\hline
\end{tabular}

Values followed by the same letter(s) on the same column are not significantly different at $\mathrm{P} \leq 0.05$. N-nitrogen, P-phosphorus

\section{3 Effects of zinc application methods on green gram dry matter and grain yield}

Zinc application methods did not have any significant $(\mathrm{P} \leq 0.05)$ observable effect on green grams dry matter and grain yield in both (Fig 3 ) and table 3 . Soil zinc recorded the highest grain yield and dry matter while control recorded the least. 
Table 3: Effect of zinc application method on green grams dry matter and grain yield and weight (kgha-1).

\begin{tabular}{llcl}
\hline Treatments & \multicolumn{2}{l}{ Grain Yield (kgha-1). } & Dry Matter (kgha-1). \\
\hline Foliar Zinc & $0.3 \mathrm{~d}$ & $0.8 \mathrm{c}$ \\
Soil Zinc & $0.4 \mathrm{~d}$ & $0.9 \mathrm{c}$ \\
Control & $0.3 \mathrm{~d}$ & $0.7 \mathrm{c}$ \\
MEAN & 0.4 & 0.8 \\
$\mathrm{CV}(\%)$ & 15.2 & 5.2 \\
LSD & 0.02 & 0.03 \\
P $\leq 0.05$ & $<.0001$ & $<.0001$ \\
\hline
\end{tabular}

Values followed by the same letter(s) on the same column are not significantly different at $\mathrm{P} \leq 0.05$.

Zinc application methods did not have any significant $(\mathrm{P} \leq 0.05)$ observable effect on green grams pods per plant and grains per pod both in (Fig 4) and table 4. Pods per plant obtained from foliar and soil applied zinc did not differ; crops applied with zinc had 39\% morer pods per plant compared to control. Soil zinc gave the highest grains per pod while control gave the least.

Table 4: Effect of zinc application methods on green grams Pods per Plant and grains per pod

\begin{tabular}{lll}
\hline Treatments & Pods per Plant & Grains per Pod \\
\hline Foliar Zinc & $13.2 \mathrm{e}$ & $11.3 \mathrm{bcd}$ \\
Soil Zinc & $14.4 \mathrm{e}$ & $12.0 \mathrm{~d}$ \\
Control & $12.9 \mathrm{e}$ & $11.0 \mathrm{~cd}$ \\
MEAN & 19.6 & 12.2 \\
$\mathrm{CV}(\%)$ & 8.2 & 9.9 \\
LSD & 0.9 & 0.7 \\
$\mathrm{P} \leq 0.05$ & $<.0001$ & $<.0001$ \\
\hline
\end{tabular}

Values followed by the same letter(s) on the same column are not significantly different at $\mathrm{P} \leq 0.05$. 
Vol. 5, No. 01; 2020

ISSN: $2456-8643$

\section{DISCUSSION}

\subsection{Effects of zinc application methods on green grams plant height and number of leaves.}

Soil zinc application method significantly increased green grams height and number of leaves compared to foliar zinc application. The significant increase in height and leaf number by soil zinc can be attributed to improve of zinc uptake by plants from the soil which plays very important role in plant metabolism by influencing the activities of hydrogenase and carbonic anhydrase, stabilization of ribosomal fractions and synthesis of cytochrome. Plant enzymes activated by $\mathrm{Zn}$ are involved in carbohydrate metabolism, maintenance of the integrity of cellular membranes, protein synthesis, regulation of auxin synthesis and pollen formation. The regulation and maintenance of the gene expression required for the tolerance of environmental stresses in plants are $\mathrm{Zn}$ dependent (Cakmak, 2008). Similar results on increased plant height when soil zinc was applied have been reported by Ahmadi (2010) in rapeseed and Khorgamy and Farnia (2009) in Chickpea. Similarly, Lonov and lonovo, (1977) conducted same experiment on rice in country or town and found that application of soil $\mathrm{Zn}$ promoted growth and leaf number compared to foliar zinc.

\subsection{Effects of zinc application methods on Dry matter, pod per plant and grain yield of green grams.}

Soil zinc significantly increased green grams dry matter, pod per plant and grain yield as compared to compared to foliar zinc treatments. The increased number of pods and subsequent seeds per pod in plants applied with soil zinc can be attributed to the high dry matter accumulation (Ghildayal et al., 1978). Good dry matter accumulation in the initial growth stages of a plant might be due to activation of different physiological processes like stomatal regulation, chlorophyll formation, enzyme activation and biochemical processes due to presence of adequate levels of trace elements (Cakmak, 2008). Similar findings are reported by Wisal et al. (1990) that $\mathrm{Zn}$ applied by soil application significantly enhanced biological yield in wheat and rice than foliar zinc. The favorable effect of soil zinc application on growth of green gram might be due to its direct influence on auxin production which in turn enhanced the elongation processes of plant development as reported by Singh and Badhoria (1984). Foliar zinc application method is not an efficient method in improving plant growth as it can burn the plant if not applied effectively. The plant may not utilize the fertilizer well in case it is applied during windy days as it will be carried away or if it rains after application as the fertilizer is washed away.

Similar results were reported by Shah et al. (1985) and Rehman and Barnard, (1988) who obtained maximum yield in lentil and maize by application of $\mathrm{Zn} 5 \mathrm{~kg}$ ha-1 as soil zinc compared to foliar zinc. Although foliar zinc application is efficient in rapid plant response, its uncomplicated method for quick improvement of plant nutritional status especially $\mathrm{Zn}$ accumulation in grains while soil zinc application method is more effective in increasing the grain yield (Erenoglu et al., 2002) 
Vol. 5, No. 01; 2020

ISSN: $2456-8643$

\section{CONCLUSIONS AND RECOMMENDATIONS}

Application of zinc through the soil was found to be more effective in promoting crop growth, nodulation rate, biomass accumulation and grain yield. Soil zinc treatment significantly increased green grams height, leaf number, dry matter, pod per plant and grain yield compared to foliar zinc treatment.

From this study it is recommended that farmers should mitigate $\mathrm{Zn}$ deficiency in green grams and therefore, improve zinc in the soil hence increase in growth and grain yield which is a potential tool to fight against $\mathrm{Zn}$ malnutrition in Kenya. Further research trails should be made to confirm these applications of $\mathrm{Zn}$ in different areas of Kenya.

\section{REFERENCES}

Abdo, F. A. (2001). The response of two mungbean cultivars to zinc, manganese and boron I. Morphological, physiological and anatomical aspects. Bulletin-faculty of agriculture university of cairo, 52(3), 445-466.

Ahmadi, M. (2010). Effect of zinc and nitrogen fertilizer rates on yield and yield components of oilseed rape (Brassica napus L.). World Applied Sciences Journal, 10(3), 298-303

Alloway, B. J. (2004). Zinc in soils and crop nutrition. In P. C. Srivastava and U. C. Gupta (Eds.), Trace elements in crop production (pp. 445-501). Beverly Hills, CA: Science Publishers, INC.

Baloch Q. B., Chachar Q. I., and Tareen M.N. (2008). Effect of foliar application of macro and micro nutrient on production of green chilies (Capsicum annuum L.). Journal of Agricultural Technology, 4: 177- 184.

Bhadoria, P. B. S. (1986). Transport of anion towards root as influenced by soil compaction. Journal of agronomy and crop science, 157(2), 127-129.

Cakmak, I. (2008). Enrichment of cereal grains with zinc: Agronomic or genetic biofortification. Plant Soil, 302, 1-17.

Doi, T. S., Marino, M. W., Takahashi, T., Yoshida, T., Sakakura, T., Old, L. J., and Obata, Y. (1999). Absence of tumor necrosis factor rescues RelA-deficient mice from embryonic lethality. Proceedings of the 1ST National Academy of Sciences Conference (pp. 2994-2999). Guanzouw University, China.

Kanyanjua, S. M., Ireri, L., Wambua, S., \& Nandwa, S. M. (2002). Acidic soils in Kenya: Constraints and remedial options.

Khorgamy, A., and Farnia, A. (2009). Effect of phosphorus and zinc fertilisation on yield and yield components of chick pea cultivars. In 9th African Crop Science, Conference Proceedings, Cape Town, South Africa, 28 September-2 October 2009 (pp. 205-208). African Crop Science Society. 
Kumar, V., Yadav, C. S., Singh, S., Goel, S., Ahmed, R. S., Gupta, S., and Banerjee, B. D. (2010). CYP 1A1 polymorphism and organochlorine pesticides levels in the etiology of prostate cancer. Chemosphere, 81(4),464-468.

Rashid, A., and Ryan, J. (2004). Micronutrient constraints to crop production in soils with Mediterranean-type characteristics: a review. Journal of Plant Nutrition, 27(6), 959-975.

Rehamn G, Barnard E.E. (1988). Yield quality and agronomic characteristics of lentil with phosphorus and Zn. Sarhad J. Agric., 4, 233-240.

Ryan, J., and El-Moneim, A. M. (2007). Implications of zinc deficiency for ameliorating toxicity (lathyrism) in grasspea. In Conf. Proc.: Zinc Crops, 9(1), 74-112.

Schmitt, A. P., Leser, G. P., Waning, D. L., and Lamb, R. A. (2002). Requirements for budding of paramyxovirus simian virus 5 virus-like particles. Journal of Virology, 76(8), 3952-3964.

Steel, R., and Torrie, J. (1980). Principles and procedures of statics: A biometric approach (2nded.). New York: McGraw Hill Publishing Company.

Thomas, J.R., K.L. Sahrawat, S.P. Wani and G. Pardhasaradhi, (2007). Widespread deficiencies of sulfur, boron and zinc in Indian semi-arid tropical oils: On-farm crop responses. J. Plant Nutr., $30,1569-1583$.

Wisal M, Iqbal M. M., and Shah, S. M. (1990). Effect of mode of application of zinc and iron on yield of wheat (Cv. Pak-81). Sarhad J. Agric 6(6), 615-618.

Wissuwa, M., Ismail, A.M., and Graham, R.D. (2007). Rice grain zinc concentrations as affected by genotype, native soil-zinc availability, and zinc fertilization. Plant and Soil. 306(1), 37-48.

Wu, C., Lu, L., Yang, X., Feng, Y., Wei, Y., Hao, H., Stoffella, P.J., and He, Z. (2010). Uptake, translocation, and remobilization of zinc absorbed at different growth stages by rice genotypes of different $\mathrm{Zn}$ densities. Journal of Agriculture and Food Chemistry, 58(2), 67676773.

Zafar, S., Nasri, M., Moghadam, H. R. T., \& Zahedi, H. (2014). Effect of zinc and sulfur foliar applications on physiological characteristics of sunflower (Helianthus annuus L.) under water deficit stress. Int J Biosci, 5(12), 87-96.

Erenoglu B., Nikolic M., Römhold V., and Cakmak I. (2002). Uptake and transport of foliar applied zinc $(65 \mathrm{Zn})$ in bread and durum wheat cultivars differing in zinc efficiency. Plant and Soil, 241(1), 251-257. 